\title{
Invitation to Discipleship: \\ Educating for Virtue in Catholic Classrooms
}

\author{
Patrick Manning* \\ Boston College School of Theology and Ministry
}

Focus on the virtues has enjoyed a recent resurgence in the field of ethics and has even influenced scholars in religious education. This influence carries positive implications for Catholic education that merit further development. In this paper, the author gleans insights from studies in virtue ethics that may be beneficially applied to Christian formation in the classroom context. The paper begins with a discussion of the relevance of the virtues to the aims of Catholic education before going on to explain how virtues are developed generally and, more specifically, how they can be developed in Catholic classrooms.

\footnotetext{
* Patrick Manning is a Ph.D. student in theology and education at Boston College's School of Theology and Ministry. He also serves part-time as clinical faculty for the Alliance for Catholic Education at the University of Notre Dame. His interests include pedagogy, teacher formation, and christology.
} 


\section{Introduction}

It is a commonplace in Catholic schools to speak of the holistic education of the student. However, how to achieve such holistic education in the details of the day-to-day is harder to say. Thomas Groome suggests, "We need an approach that informs, forms, and transforms people in the habitus, in the conviction and constant disposition to do what they discern to be God's will in all circumstances and at every level of existence."1 Groome's proposal of educating for habitus evidences the influence of a recent resurgence of scholarly interest in the virtues. I take this resurgent interest, generally, and Groome's application, in particular, to bode well for Catholic education. Indeed, the field of virtue ethics - virtue formation especially —offers fertile ground for a budding approach to Christian religious education.

It is the aim of this paper to examine some insights from virtue ethics and articulate concrete ways in which these insights can be applied to Christian formation. Acknowledging that virtue formation is a multifaceted endeavor, the paper will focus on the possibilities for the classroom context specifically. It will begin by discussing the relevance of the virtues to the aims of Catholic education. The remainder of the paper will focus on explaining how virtues are developed generally and, more specifically, how they can be developed in Catholic classrooms.

\section{The Virtues: A Profile of Discipleship}

Christian education, as carried out from the birth of Christianity, has always been concerned first and foremost with making disciples of Christ. Indeed, this is the task Jesus leaves to his apostles before ascending to the Father: "Go therefore and make disciples of all the nations...teaching them to obey everything that I have commanded you" (Mt 28:19). This call to form disciples has been echoed in our own time by John Paul II, who in Catechesi Tradendae describes catechesis as "the whole of the efforts within the Church to make disciples." Granting that this task constitutes the ultimate end of Christian education, we must ask further: what does a life of discipleship look like? To answer this question we may beneficially turn to the realm of virtue ethics.

Describing exactly what it means to be a disciple is not an easy task. It seems simple enough at first blush, but more sustained efforts to provide a profile of discipleship prove more difficult. As Timothy O'Connell says in Making Disciples, "In one sense, it is a single answer...love God and neighbor. But in another sense, it is a highly differentiated answer, a multiplicity of situationally pertinent answers." ${ }^{3}$ O'Connell is far from alone in affirming the

\footnotetext{
${ }^{1}$ Thomas H. Groome, Will There Be Faith? (New York: Harper One, 2011), 107.

${ }^{2}$ John Paul II, Catechesi Tradendae [On Catechesis in Our Time], Vatican website, October 16, 1979, <http://www. vatican.va/holy_father/john_paul_ii/apost_exhortations/documents/hf_jp-ii_exh_16101979_catechesitradendae_en.html>,\#1.

${ }^{3}$ Timothy O'Connell, Making Disciples (New York: The Crossroad Publishing Company, 1998), 13.
} 
complexity of this matter. Nevertheless, most scholars writing in this area can at least agree about the nature of the question. When asking what it means to be a disciple, theologians like O'Connell, William Spohn, and James Keenan, to name a few, all agree that this is a question of identity and not just conduct.

For this reason many ethicists see a natural connection between the concept of discipleship and the virtues. In his book, Jesus and Virtue Ethics (co-authored with Daniel Harrington), James Keenan draws out the nature of this connection:

Who more than Jesus beckons us to consider the question about the people we can become? In Scripture, Jesus invites us to become his disciples...Christian ethicists saw, then, in the virtues an enormous opportunity for answering the challenge of Vatican II (Optatum totius 16), which admonished moral theologians to draw more fully on the teaching of Scripture and to throw light upon the exalted vocation of the Christian. ${ }^{4}$

When dealing with questions of identity, virtue ethics is a natural fit. As William Spohn notes, virtue ethics focuses on the agent's identity, attributing significance to actions as a display of the agent's values and commitments. ${ }^{5}$ Virtue ethicists-Keenan cites Gilbert Meilaender, Joseph Kotva, and Joseph Woodill as other examples - find in the virtues a ready made way of talking about discipleship. To be sure, there are as many different ways of being a disciple as there are people. Still, we can identify certain marks that consistently characterize followers of Christ. These marks of character are what we mean when we speak of virtues.

For Christians the concept of virtue implies a teleology. I apply the term here in the sense that God has called human beings to be a certain way, to realize a particular identity. We have identified this identity as that of a disciple. Some philosophers and theologians use different language to talk about the goal of human existence. Alasdair MacIntyre cites common appeal to "human flourishing"6 while Bernard Lonergan speaks of human "authenticity."7 Regardless of the specific language employed, most scholars writing on morality presuppose a telos to human life. From this it follows that, in the words of Paul Wadell, "Virtues are acts that take their shape from the "end' of our life." 8 The Catechism of the Catholic Church, therefore, defines virtues as "habitual perfections of intellect and will that govern our actions, order our passions, and guide our conduct according to reason and faith." "Use of such language implies that the virtues "order our passions" and "guide our conduct" toward some end. MacIntyre likewise offers a definition reflective of such a teleology:

\footnotetext{
4 Daniel Harrington and James Keenan, Jesus and Virtue Ethics (Lanham, Maryland: Rowman \& Littlefield Publishers, 2002), 24.

${ }^{5}$ William Spohn, "Return to Virtue Ethics," Theological Studies, 53 (1992): 60-75.

${ }^{6}$ Alasdair MacIntyre, After Virtue, $2^{\text {nd }}$ ed. (Notre Dame, IN: University of Notre Dame Press, 1984$), 162$.

${ }^{7}$ Bernard Lonergan, Method in Theology (Toronto: University of Toronto Press, 2007), 254.

${ }^{8}$ Paul Wadell, The Primacy of Love: An Introduction to the Ethics of Thomas Aquinas (Eugene, Oregon: Wipf \& Stock, 1992), 115.

9 Congregation for Clergy, Catechism of the Catholic Church (Washington, D.C.: United States Catholic Conference, 2000), \#1804.
} 
The virtues therefore are to be understood as those dispositions which will not only sustain practices and enable us to achieve the goods internal to practice, but which will also sustain us in the relevant kind of quest for the good, by enabling us to overcome the harms, dangers, temptations and distractions which we encounter, and which will furnish us with increasing self-knowledge and increasing knowledge of the good. ${ }^{10}$

In addition to emphasizing how virtues aid us on our way to our proper moral end, MacIntyre describes virtues as both skills and dispositions. This distinction highlights the fact that virtues must be not only learned but also formed through individual and communal reinforcement. It will be the aim of the remainder of this paper to describe the various elements involved in this formation process. $^{11}$

\section{Forming Virtue in Catholic Classrooms: General Principles and Concrete Strategies}

Forming virtue in the classroom context presents its own unique challenges. First among these is the limited amount of time that teachers have to work with students. As suggested by the above definitions of virtue as a habit or disposition of character, forming virtue takes time. It is not so much a matter of ensuring that students can repeat a particular action as it is a matter of ingraining a characteristic way of acting over time. In this regard teachers-particularly teachers of middle school and above - are limited because they see their students for only a short time each day. That classroom time is further constricted by teachers' responsibility to cover certain material and assess students' learning. This time spent mastering content and intellectual skills is obviously important, but it limits the amount of time teachers can devote to the sorts of activities that conduce to the development of virtue.

In addition to time constraints, teachers are limited by the physical space of the classroom. As I will argue below, virtues can only be developed by choosing virtuous actions in the midst of life's day-to-day experiences. Even allowing for the occasional field trip or service opportunity, formal schooling generally lacks the "real-world" dimension in which virtue is forged. ${ }^{12}$ Another challenge to virtue formation in the classroom context is the limits on the degree of familiarity permissible between teacher and students. While teachers can undoubtedly exert a moral influence on their students, concerns for maintaining a professional distance usually prevent teachers from forging friendships with students the likes of which the latter will need to form elsewhere if they are to embrace a life of virtue. A final challenge is the

\footnotetext{
${ }^{10}$ MacIntyre, After Virtue, 219.

${ }^{11}$ Due to space constraints, in the following pages I will speak of virtue formation in general rather than formation of any virtue in particular. Nevertheless, I write with the traditional theological and cardinal virtues in mind.

${ }^{12}$ John Dewey would contend, "Anything which can be called a study... must be derived from the materials which at the outset fall within the scope of ordinary life-experience." (John Dewey, Experience and Education [New York: Collier Books, 1963], 73). However, my concern is more with classroom learning as it usually occurs and, besides, no school however progressive will ever be able to fully simulate the variety and complexity of daily life as it occurs outside school walls.
} 
compulsory nature of formal schooling. One can only grow in virtue through personal decision and commitment. Though these are by no means necessarily excluded from the classroom context, students are less inclined to such activity when they have no choice regarding their involvement in the class.

Should we then conclude from this consideration of the limitations of classroom education that teachers have no hopes of forming their students in virtue? The remainder of this section will suffice to demonstrate that this is not the case. Keeping in mind these limitations, the ensuing discussion will draw from general guidelines for virtue formation some concrete suggestions of how teachers can encourage students' growth in virtue.

First, we should consider generally how virtue develops. Thomas Aquinas observes that human beings have a capacity for virtue, which is not to be mistaken for natural possession of virtue. ${ }^{13}$ The moral agent must develop the virtues through sustained effort. As Patricia Lamoureux and Paul Wadell say, "Acquiring the virtues... is a matter of forming a capacity into a disposition and a disposition into a habit."14 Lamoureux and Wadell draw out how one develops dispositions into habits: "We are virtuous when through a long process of habituation our disposition to think, act, and feel in certain ways becomes our regular and expected way of being." 15 In sum, virtue formation is not a process that occurs automatically or even by intentionally performing isolated moral acts. Rather, it is the development of an innate capacity through sustained, intentional effort.

Aquinas describes three stages in the process of virtue acquisition: discipline, progress, and maturity. ${ }^{16}$ These stages can be summarized no better than did Craig Steven Titus, who said:

First, growth in virtue involves a disciplined distancing of oneself from what is destructive, empty, or undeveloped. It involves employing law as a sure rule to protect our burgeoning affections and cognitions as well as self-mastery to aid us to resist disordered emotions and to act morally with greater consistency. Second, we advance toward a perfective goal through the habituation (teleological growth) of our malleable capacities. In our quest for goodness, we start to make progress in virtue, encouraged by family, teachers, friends, and the community. We develop patterns of being that are more receptively and actively disposed to goodness and truth, tending toward self-preservation and life in family and in society. Finally, we obtain maturity and rest, as well as joy and spontaneity, in the internal exercise of virtuous ways that express a creative freedom of excellence. Over time, our moral powers can continue to be perfected in the pursuit of personal acts and communal practices that accord with reason, including faith-informed reason. ${ }^{17}$

The reader will discern these three stages in the descriptions of guidelines for virtue formation that follow here, most of which fall under the first two stages.

\footnotetext{
13 Thomas Aquinas, Summa Theologica, trans. Fathers of the English Dominican Province (New Advent, 2008), $<\mathrm{http}$ ://www.newadvent.org/summa/2051.htm\#article1>, I.II, q.51, a.1, c.

${ }^{14}$ Patricia Lamoureux and Paul J. Wadell, The Christian Moral Life (New York: Orbis Books, 2010), 120.

${ }^{15}$ Lamoureux and Wadell, The Christian Moral Life, 120.

${ }^{16}$ Aquinas, Summa Theologica, <http://www.newadvent.org/summa/3024.htm\#article9>, II.II, q.24, a.9.

${ }^{17}$ Craig Steven Titus, "Moral Development and Making All Things New in Christ," The Thomist 72 (2008), 247-8.
} 
In considering these stages of virtue formation the question arises: why would anyone undertake this process in the first place? Since growth in virtue is by no means automatic, people must find a reason to work toward this particular goal for human existence. Hence, we recognize the importance of teachers inviting students into this process when students are not yet able to recognize the good inherent in the virtues for themselves. This invitation can take any number of forms. Kenneth Strike highlights two: "Engaging students...in the process of initiation [into virtuous practices] may be motivated through appeal to, or manipulation of, external goods. Alternatively it can be mediated by trust. The latter approach, I argue, is more conducive to human flourishing."18 As Strike suggests, not all methods of motivation are equally salutary. While external goods may entice students to exhibit behavior that appears virtuous (e.g., a gold star for kindness toward one's classmates), such superficial motivations will have to give way to more internalized ones if students are ever to grow into real virtue. Strike proposes trust in a virtuous mentor as an example of the sort of motivation that leads naturally to such internalization. Though students do not yet recognize the good of the virtues for themselves, they may imitate the example of mentor figures because of the confidence they have in them.

The two options presented by Strike are not the only two available. In fact, the credibility of the teacher is only one of three forms of rhetorical persuasion distinguished by Aristotle. ${ }^{19} \mathrm{He}$ explains, "We believe good men more fully and more readily than others: this is true generally whatever the question is...his character may almost be called the most effective means of persuasion he possesses." 20 Applied to our discussion, we might say that simply by embodying the virtues, teachers offer students enticement to take up the practice themselves. If students see someone they respect and admire living well, they will want to imitate that manner of living. In addition to providing a virtuous example, teachers can further facilitate student initiation into the practice of virtue by explicitly making connections between the values they personally hold and the good they enjoy in their lives as a result. In this regard, how teachers speak of Scripture, Church teaching, liturgical observances, etc. is as important as what they say. If they speak of these things as so many topics to be covered for the test, students will treat them as such. If they speak of them with reverence and joy, students will take notice.

The other two forms of persuasion mentioned by Aristotle are logos and pathos. Logos refers to logical argument or reasonableness. When speaking of matters pertaining to the Christian faith, teachers ought to strive to demonstrate the reasonableness of the Church's beliefs. This is especially important in the case of adolescents, who at this stage in their cognitive development are highly attuned to logical argumentation. It is true that much of the Christian

\footnotetext{
${ }^{18}$ Kenneth A. Strike, "Trust, Traditions and Pluralism: Human Flourishing and Liberal Polity," in Virtue Ethics and Moral Education, eds. David Carr and Jan Steutel (New York: Routledge, 1999), 232.

${ }^{19}$ Aristotle, "Rhetoric," in The Basic Works of Aristotle, ed. Richard McKeon (New York: Random House, 2001), 1329. See also, Thomas H. Groome, Will There Be Faith? (New York: Harper One, 2011), 149-51 for a discussion of how Christian educators can employ this rhetoric for the purposes of a "new apologetic."

${ }^{20}$ Aristotle, "Rhetoric," 1329.
} 
faith is at its core a Mystery, but this does not mean that we leave reason behind when we profess our faith. Indeed, the Church has repeatedly affirmed the compatibility of faith and reason. ${ }^{21}$

Pathos refers to an appeal to one's emotions and desires. For example, when admonishing one's students to take up a life of virtue, teachers ought to appeal to their students' desire for happiness and fulfillment. If they understand virtuous living as the means to their happiness, students will be more inclined to begin and persevere in the necessary work of selfdiscipline. This form of persuasion might also incorporate use of artwork, music, and stories. By such means teachers can get students excited about the faith, intriguing them enough to delve further into the Christian Tradition.

Having delineated some methods of drawing students into the process of virtue formation, we might next ask: What is to guide their efforts once they begin the process? Given the infinite possibilities for interpreting life's experiences, what is needed is a unifying vision whereby fledgling Christians can make sense of themselves, the world, and their action therein. In the words of Strike, "experience is dependent on the acquisition of concepts. We cannot experience what we cannot conceive." 22 Without a unifying vision we cannot imagine how we ought to act. As Iris Murdoch says, "True vision occasions right conduct." 23 The Catholic Church offers such a vision developed out of its lived response to the revelation of the Triune God, particularly the teaching, life, death, and resurrection of Jesus Christ.

In order for Christians to benefit fully from this vision, however, they must come to see it through their own eyes rather than unreflectively assenting to Church teaching. Moral theologians refer to the capacity for generating such a personal vision with the term "imagination." Craig Dykstra describes imagination as "that process in the human psyche which makes meaningful intercourse with the world possible." 24 For Christians, this meaningful intercourse is guided by the teaching and example of Christ. Yet it would be misguided to reduce Christian imagination to literalist adherence to the teachings of Christ or a rigid imitatio Christi. William Spohn argues, "No abstract formula, however, can epitomize Jesus of Nazareth, because his meaning is inseparable from his story...We extend a pattern by analogy since we move from the recognizable shape in the first instance to novel situations within certain limitations." 25 Christians in every age since the time of Christ have found themselves in situations that go beyond Jesus' own life experiences. This makes a strict imitation impossible. Instead they must use their imagination to discern, based on Jesus' context and example, the analogous action most appropriate for their own context. It is for this reason that theologians describe the properly Christian imagination as the "analogical imagination." "26 Given the insufficiency of pious abstractions and strict imitation for a life of authentic discipleship, we must conclude along with

\footnotetext{
${ }^{21}$ See, e.g., John Paul II, Fides et Ratio, Vatican website, September 14, 1998, <http://www.vatican.va/holy_father /john_paul_ii/encyclicals/documents/hf_jp-ii_enc_15101998_fides-et-ratio_en.html>.

${ }^{22}$ Strike, "Trust, Traditions and Pluralism," 232.

${ }^{23}$ Iris Murdoch, The Sovereignty of Good (New York: Schocken Books, 1970), 66.

${ }^{24}$ Craig Dykstra, Vision and Character (New York: Paulist Press, 1981), 76.

${ }^{25}$ William Spohn, “Jesus and Christian Ethics,” Theological Studies, 56 (1995), 102.

${ }^{26}$ Most notable among these is David Tracy, The Analogical Imagination (New York: Crossroad, 1981).
} 
Dykstra, "The transformation of the moral life, the transformation of character, is a transformation of the imagination." 27

The importance of a Christian vision and imagination for a life of virtue is now evident. The question then follows, 'How can educators extend this vision to their students?' Murdoch and Lamoureux and Wadell believe helping students to overcome illusions about reality to be an essential first step. Lamoureux and Wadell cite egotism and consumerism as two examples of common illusions that distort our perception of reality. ${ }^{28}$ Teachers can thus prepare the soil of students' hearts to receive the seed of the Gospel by demonstrating to them that such selfcenteredness and fixation on material possessions fail to provide true happiness. Real-life examples from which teachers might choose are never in short supply.

In addition to sweeping away distorted views of reality, Christian educators ought to immerse students actively in a Christian worldview. Teachers will find a number of resources at their disposal for this purpose. One particularly powerful tool is the use of images and symbols. Images, even more than rational accounts, are so powerful because, Harriet Crabtree explains, "because of their blend of cognitive, affective, and motivational elements." ${ }^{29}$ Furthermore, Timothy O'Connell, citing the research of neurologist Antonio Damasio, observes that our knowledge is stored in the form of images. ${ }^{30}$ Consequently, in the words of Dykstra, "Our very consciousness rests on an unceasing flow of such images." 31 Thus, when teachers present their students with Christian images and symbols - the tree of knowledge of good and evil, the cross, the blood of martyrs - they influence the very way students think, remember, and perceive. Frequent exposition of Christian artwork is one way of accomplishing this end.

Another powerful means of forming students' vision is storytelling. Scholars from a variety of disciplines testify to the natural power of stories. William Spohn, for example, writes:

Contemporary cognitive psychology agrees with narrative theology that humans need a moving dramatic unity, a story with a beginning, middle, and end, to bring integrity to their personal histories. No other imaginative device can synthesize our diverse moments of experience into a coherent whole. ${ }^{32}$

Spohn finds ready support for this claim in the writings of philosopher Alasdair MacIntyre, theologians Stanley Hauerwas, Stephen Crites, and Craig Dykstra, and educational psychologist Mark Tappan, to name a few. ${ }^{33}$ Because we naturally conceive of our own lives in narrative fashion, the practice of storytelling adds vicariously to the storehouse of experience that forms our identity. ${ }^{34}$ The stories we hear mingle with the stories we live. As a result, the more we hear

\footnotetext{
${ }^{27}$ Dykstra, Vision and Character, 78.

${ }^{28}$ Lamoureux and Wadell, The Christian Moral Life, 27-32.

${ }^{29}$ Harriet Crabtree, The Christian Life: Traditional Metaphors and Contemporary Theologies "The Christian Life," in Harvard Dissertations in Religion 29 (Minneapolis: Fortress, 1991), 3.

${ }^{30}$ O'Connell, Making Disciples, 69.

${ }^{31}$ Dykstra, Vision and Character, 77.

${ }^{32}$ Spohn, "Jesus and Christian Ethics," 105.

${ }^{33}$ See O'Connell, Making Disciples, 119 for a discussion of these various authors.

${ }^{34}$ Ibid., 126.
} 
stories of virtuous deeds, the more the story we live takes on a similar character. Craig Dykstra puts it well: "To be of good character is to have and to be a story that makes sense in the light of what the world is really like.",35

Fortunately for educators, the Christian Tradition offers a veritable treasure trove of stories. The most prominent source is the Bible. Scripture is particularly well suited to the task of virtue formation because the inspired authors wrote with the explicit intention of transforming the character of their readers. Spohn explains, "The New Testament writers attempt to convert the imaginations of Christians by parables, metaphors, and stories. They want their readers to see life in a new way and to act in radically different ways. ${ }^{, 36}$ In the same vein, George Lindbeck affirms, "A scriptural world...supplies the interpretive framework within which believers seek to live their lives and understand reality." 37 Jesus' parables, because of their pithy wording and vivid imagery, can exercise an especially powerful influence on Christians' thinking. Teachers will thus do well to immerse students in Scripture as often as possible. This may mean, for example, praying with the readings of the day at the beginning of class, incorporating relevant passages when discussing topical issues, or assigning Scripture readings for homework. Encouraging students to imagine themselves in the stories of Scripture can also be a highly effective way of effecting such an immersion.

In addition to the Bible, teachers may beneficially draw upon stories about saints and other virtuous people. Often students perceive the events and context of the Bible as far removed from the goings-on of their own lives. For this reason, more recent examples of virtuous living can be a helpful supplement. It is important for students to see concrete examples of how virtue is practiced and that such practices constitute a way of life that others have found life-giving. Alasdair MacIntyre claims, "To enter into a practice is to enter into a relationship not only with its contemporary practitioners, but also with those who have preceded us in the practice, particularly those whose achievements extended the reach of the practice to its present point." 38 Indeed, stories of people who have lived virtuous lives are often more powerful than moral prescriptions. In the words of author Philip Pullman, "'Thou shalt not' is soon forgotten, but 'Once upon a time' lasts forever." 39

Personal experience is also tremendously important for the formation of Christian imagination. In reality, the dynamic between experience and imagination is a two-way street. O'Connell draws upon the research of Antonio Damasio to show how our experiences supply the mental images that give shape to our thoughts. ${ }^{40}$ Conversely, O'Connell cites John Grinder's theory of "Neuro-Linguistic Programming," which purports, "We can change our experiences by

\footnotetext{
${ }^{35}$ Dykstra, Vision and Character, 52.

${ }^{36}$ William Spohn, Go and Do Likewise (New York: Continuum, 1999), 67.

${ }^{37}$ George Lindbeck, The Nature of Doctrine (Louisville, KY: Westminster John Knox Press, 2009 ), 117.

${ }^{38}$ MacIntyre, After Virtue, 194.

${ }^{39}$ Philip Pullman, 1996 Carnegie Medal acceptance speech, <http://www.randomhouse.com/features/pullman/ author/carnegie.php $>$.

${ }^{40}$ O’Connell, Making Disciples, 105.
} 
changing our [mental] images."41 Of particular interest to Christian educators are Grinder's two suggestions for how to change one's experiences. On the one hand, teachers may lead students in imagination exercises whereby they imagine positive images from their own perspective and dissociate themselves from negative images. On the other hand, teachers may employ a technique Grinder terms "reframing" in which participants, rather than criticizing or lamenting particular feelings and urges (e.g., for food or tidiness), acknowledge them as friends that lead us to happiness when used properly. In this way teachers can not only guide students through new experiences (vicarious and actual) conducing to virtue development but also refashion how students perceive the experiences they already have.

In this way we can see the central role of forming students' vision and imagination in the process of virtue formation. Our images and stories affect how we think about ourselves, the world, and our action therein. For this reason the frequency and manner in which teachers employ Christian stories, symbols, and language is of the utmost importance. Nevertheless, as William Spohn points out, simply employing such stories, symbols, and language does not necessarily make students virtuous: "Because the imagination is as susceptible to prejudice and sin as every other human faculty, other controls on analogical reflection are required, such as ordinary standards of morality, consequences, and community practice." ${ }^{22}$ It is to these other elements in virtue formation that we turn in these final pages.

Perhaps the most fundamental of insights into virtue formation is that it takes practice. Aristotle writes, "We become just by doing just acts, temperate by doing temperate acts, brave by doing brave acts." ${ }^{\text {P3 }}$ Picking up on the thought of his philosophical mentor, Aquinas similarly notes, "a habit of virtue cannot be caused by one act, but only by many." 44 There is no such thing as a virtuous action in isolation. Virtuous actions flow from a virtuous character, and that character can only be formed through a history of choosing the good.

Modern scientific research sheds some light on the matter. Albert Bandura's investigations into "social learning theory" have convinced him of the necessity of individuals actually performing a particular practice in order for observational learning to occur successfully. ${ }^{45}$ Research in the field of neurology offers a biological explanation for why this is so. O'Connell reports, "if Antonio Damasio's research is correct, the cultivation of values and the making of personal and moral judgments are centrally bodily and emotional processes, not just intellectual ones." influenced by our actions and experiences. O'Connell points out that this scientific finding confirms what has long been held as true in the Christian Tradition. He cites as evidence the traditional distinction between cognitio speculativo and cognitio aestimativo, the latter of which

\footnotetext{
${ }^{41}$ Ibid., 107-9.

42 Spohn, "Jesus and Christian Ethics," 104.

43 Aristotle, "Nicomachean Ethics," in The Basic Works of Aristotle, ed. Richard McKeon (New York: Random House, 2001), 952.

${ }^{44}$ Aquinas, Summa Theologica, <http://www.newadvent.org/summa/2051.htm\#article3>, I.II, q.51, a.3.

${ }^{45}$ See O’Connell, Making Disciples, 91-94.

${ }^{46}$ Ibid., 70 .
} 
includes felt appreciation. ${ }^{47}$ Given these observations, O'Connell advises, "If people who claim to be Christian do not regularly spontaneously respond to moral dilemmas in a 'Christ-like way,' the solution lies in the introduction of additional experiences." 48

These experiences may take any number of forms. While still young, children are not yet able to recognize the value of virtuous actions for themselves. Consequently, their educators must ensure that they undergo the right types of experiences. To this effect Joel Kupperman notes, "Childhood patterning reinforced by pleasure and pain is crucial, in Aristotle's view, to the formation of good habits." 49 This reinforcement need not entail physical disciplining so much as enforcing a system of reward and punishment. Rules thus play an obvious role in early virtue formation. Eventually, however, external compulsion must give way to internalized habit if students are ever to become virtuous people. MacIntyre notes, "no rule or set of rules by itself ever determines how to respond rightly."50

Essential to the development of such habit is practice making spontaneous ethical decisions in the context of the everyday. MacIntyre explains, "initially what the child needs to learn is how to recognize the salient features of each situation immediately, what the relevant goods, harms, and dangers are in each situation, and what the virtues require by way of response." ${ }^{51}$ No rule or moral precept covers every ethical situation one encounters during the course of a lifetime. Therefore, to the extent possible Christian educators should provide students with opportunities to engage real-life ethical decisions. With the exception of the occasional field trip or service opportunity, teachers are limited in this regard by the bounds of their classroom. Notwithstanding, MacIntyre suggests this need not be a problem:

But we would make a mistake, if we inferred from this that some part of the child's education has to be set apart for specifically moral instruction. Just as the virtues are exercised in the whole range of our activities, so they are learned in the same range of activities, in those contexts of practice in which we learn from others how to discharge our roles and functions. ${ }^{52}$

From how they take tests to how they respond to classmates' comments, students face ethical choices everyday in the classroom. Teachers can turn these situations into teachable moments by drawing students' attention to them and encouraging students to be intentional about how they act when such situations arise.

In this last paragraph I have already anticipated another essential element in virtue formation, namely, critical reflection. In order for a virtue to be a virtue it must be intentional. A person may naturally feel compassion toward others, but unless that disposition is something that individual has intentionally cultured over time it cannot be considered a virtue. The result of such

\footnotetext{
${ }^{47}$ Ibid.

${ }^{48}$ Ibid., 74.

49 Joel J. Kupperman, "Virtues, Character and Moral Dispositions," in Virtue Ethics and Moral Education, eds. David Carr and Jan Steutel (New York: Routledge, 1999), 211.

${ }_{50}^{50}$ MacIntyre, Dependent Rational Animals, 93.

${ }^{51}$ Ibid.

${ }^{52}$ Ibid., 88-9.
} 
intentional, consistent virtuous living is phronesis, or practical wisdom. Practical wisdom in MacIntyre's account involves distinguishing between answers to the questions 'What do I want?' and 'What is it best for me to do? ${ }^{53}$ Only when a person is able to distinguish the two and freely choose the latter amidst the complexity of real-life decisions can that person be said to exhibit practical wisdom. ${ }^{54}$

Intentionality presumes understanding. From this fact it follows that educators can promote their students' growth in practical wisdom by helping them to better understand themselves, the world, and the Christian Tradition. Concerning the first of these, Joel Kupperman claims a sense of self unified across time is necessary because "[a]ny kind of good character also requires the ability to take (and maintain) responsibility for actions, and for that matter to feel gratitude for what was done more than a short while ago." ${ }^{.55}$ Teachers can encourage the requisite introspection by asking students questions, allowing time in class for journaling, and even giving homework assignments that require students to examine their habits, values, environment, friends, family background, etc. In order to exercise virtue students must also know the world in which that virtue is exercised. Along these lines, Kupperman points out, "Confucius also repeatedly emphasizes empirical knowledge of the world as a guide to goodness. ${ }^{, 56}$ Here the value of engaging history and current events in class discussions is evident. Lastly, the above discussion of vision will suffice to demonstrate the importance of students knowing the Christian faith if they are to view the world as it truly is. With this end in mind, teachers must ensure that their students achieve adequate understanding of Christian Scripture, creeds, doctrine, and practices.

We now come to what most scholars regard as the single most important element in virtue formation - community. In the words of O'Connell, "It is the group, then, that is the home of values. And if this is true, then the making of disciples may really be a process of creating communities of discipleship, homes where the value priorities of the disciple flourish." 57 O'Connell arrives at this conclusion after examination of a whole body of research in several disciplines. He cites, for example, the findings of psychologist Elaine Hatfield et al that value preference modification was more effective when focused on groups rather than individuals. ${ }^{58}$ Research by psychologist Norma Haan and sociologist Samuel Oliner yielded corroborating results. $^{59}$

We can identify a number of ways in which communities influence the growth in virtue of individual members. For one, the stories, symbols, and language that we earlier determined are so crucial in moral development arise from the community. As Stryker and Serpe say, "We

\footnotetext{
${ }^{53}$ See ibid., 70. Cf. Aquinas on concupiscible vs. irascible appetites, Summa Theologica, $<$ http://www.newadvent. org/summa/2023.htm>, I.II, q.23.

${ }_{55}^{54}$ MacIntyre answers the question of how practical wisdom is formed in Chapter 8 of Dependent Rational Animals.

${ }_{56}^{55}$ Kupperman, "Virtues, Character and Moral Dispositions," 214.

${ }^{56}$ Ibid., 213.

${ }^{57}$ O’Connell, Making Disciples, 85-6.

${ }^{58}$ Ibid., 76.

${ }^{59}$ Ibid., 81-85.
} 
become objects to ourselves by attaching to ourselves symbols that emerge from our interaction with others, symbols having meanings growing out of that interaction." ${ }^{60}$ In a similar fashion, Dykstra comments, "communities have historical dramas of their own that, as I become a member of that community, I come to adopt as part of my own drama."61 The stories, symbols, and language of the communities in which we live almost inevitably become our own. Teachers, like all members of Christian communities, should therefore take care to heed the words of St. Paul: "Never let evil pass your lips; say only the good things men need to hear, things that will really help them" (Eph 4:29).

Not only do communities provide the occasion for virtuous living; ${ }^{62}$ they also supply the models of virtue and accountability and support we need to grow in this way. We can learn to be virtuous only if we have an example of how virtue is lived in our own context. Joseph Kotva writes to this effect, "We learn the virtues by imitating worthy role models, listening to the advice of virtuous friends and teachers, hearing the stories of virtuous people." ${ }^{, 63}$ The research of psychologists Daniel Levinson and Albert Bandura, to name just two, provides scientific support for this bit of common wisdom. ${ }^{64}$

Beyond simply providing models for imitation, communities provide the accountability we all need to remain on the path to virtue. According to MacIntyre, "It is by having our reasoning put to the question by others, by being called to account for ourselves and our actions by others, that we learn how to scrutinize ourselves as they scrutinize us..." ${ }^{\text {, }}$ This is especially the case, MacIntyre notes, with friends who know us well. These observations of MacIntyre's draw out both the possibilities and limitations placed upon teachers as members of a Christian community. On the one hand, as adult figures with whom students spend a considerable amount of time, teachers are ideally suited to serve as models of virtue, challenge students' erroneous assumptions, and otherwise build up a community of virtue within the classroom. On the other hand, typically teachers are not friends with their students in the sense intended by MacIntyre, which is only to say that they cannot be all things to all people. Those students are most likely to become virtuous individuals who form friendships outside the classroom with other virtuous individuals.

The influence of community in forming its members in virtue cannot be emphasized enough. In the words of O'Connell, “it is by our experiences of and with other persons that our moral sensibilities are most decisively shaped." 66 This being the case, it is absolutely essential that teachers nurture a classroom community where virtue can thrive. In addition to modeling virtuous behavior and insisting on the same from students in class, teachers can build community

\footnotetext{
${ }^{60}$ Ibid., 97, quoting Stryker and Serpe, "Commitment," 202.

${ }^{61}$ Dykstra, Vision and Character, 55.

${ }^{62}$ See Lamoureux and Wadell, The Christian Moral Life, 123 and MacIntyre, Dependent Rational Animals, 74 for discussions of the inherently relational nature of virtuous practices.

${ }^{63}$ Joseph Kotva, The Christian Case for Virtue Ethics (Washington, D.C.: Georgetown University Press, 1996$), 6$.

${ }^{64}$ See O'Connell, Making Disciples, 88-94 for the relevant discussion of the work of Levinson and Bandura.

${ }^{65}$ MacIntyre, Dependent Rational Animals, 148.

${ }^{66}$ O’Connell, Making Disciples, 76.
} 
by doing things like celebrating students' accomplishments publicly and providing ample opportunities for discussion and group work among students.

\section{Conclusion}

It has been the aim of this paper to discuss the possibilities for virtue formation in the classroom context. As we have seen, the process of forming virtue is a multifaceted endeavor that occurs at every stage of life. It can and must begin before students start their formal education, continue afterwards, and occur outside school walls throughout that period of schooling. Classroom instruction alone will never suffice to form truly virtuous individuals. Nevertheless, it should by now be clear that a wide array of possibilities for forming students in virtue present themselves to teachers. By seizing these opportunities and making connections with other formative elements outside the classroom, teachers can greatly aid the work of the Christian community in forming disciples. 